\title{
BIOMASS PRODUCTION, YIELD AND CHEMICAL COMPOSITION OF PEPPERMINT ESSENTIAL OIL USING DIFFERENT ORGANIC FERTILIZER SOURCES
}

\author{
Produção de biomassa, rendimento e composição química do óleo essencial de \\ hortelã-pimenta usando diferentes fontes de adubação orgânica
}

\author{
Andressa Giovannini Costa ${ }^{1}$, Suzan Kelly Vilela Bertolucci ${ }^{2}$, Jorge Henrique Chagas ${ }^{3}$, \\ Elza Oliveira Ferraz ${ }^{4}$, José Eduardo Brasil Pereira Pinto ${ }^{4}$
}

\begin{abstract}
Mentha $\mathrm{x}$ piperita L. is an aromatic and medicinal species belonging to the family Lamiaceae that is popularly known as peppermint. The aim of this study was to evaluate the effects of organic fertilizer sources on the biomass production, yield and chemical composition of peppermint (Mentha piperita L.) essential oil. The experiment was conducted using a completely randomized design (CRD) with a 2 x 5 factorial scheme, two sources of manure (cattle and poultry), five doses $\left(0,3,6,9\right.$ and $\left.12 \mathrm{~kg} \mathrm{~m} \mathrm{~m}^{-2}\right)$ and four replicates. Different doses of cattle and poultry manure significantly affected plant biomass production and the responses of other variables, including leaf area, leaf weight ratio, leaf area ratio, root:shoot ratio, yield and chemical composition. Organic fertilizer doses of $9.0 \mathrm{~kg} \mathrm{~m}^{-2}$ cattle manure and $8.3 \mathrm{~kg} \mathrm{~m}^{-2}$ poultry manure to obtain the maximum total dry biomass. The highest yield of essential oil was obtained by applying $11.8 \mathrm{~kg} \mathrm{~m}^{-2}$ poultry manure. Differences in the chemical composition of the essential oil were observed for only three components (menthone, pulegone and menthyl acetate) without significant changes in the menthol content.
\end{abstract}

Index terms: Mentha piperita, cattle manure, poultry manure, growth analysis.

\begin{abstract}
RESUMO
Mentha $\mathrm{x}$ piperita L. é uma planta aromática e medicinal pertencente à família Lamiaceae, popularmente conhecida como hortelã-pimenta. No trabalho, objetivou-se verificar o efeito das fontes de adubação orgânica na produção de biomassa, no rendimento e na composição química do óleo essencial de hortelã-pimenta (Mentha piperita L.). O experimento foi conduzido em DIC, em esquema fatorial 2 x 5, com duas fontes de esterco, bovino e avícola, e cinco doses $\left(0,3,6,9\right.$ e $\left.12 \mathrm{~kg} \mathrm{~m}^{-2}\right)$, com quatro repetições cada. As diferentes doses de estercos bovino e avícola influenciaram significativamente de forma benéfica a produção de biomassa das plantas e também outras variáveis de crescimento como área foliar, razão de peso foliar, razão de área foliar, relação raiz:parte aérea, rendimento e composição química do óleo de hortelã-pimenta. Utilizar adubação orgânica para a obtenção máxima de biomassa seca total as doses de $9,0 \mathrm{~kg} \mathrm{~m}^{-2}$ de esterco bovino e $8,3 \mathrm{~kg} \mathrm{~m}^{-2}$ de esterco avícola. O maior rendimento de óleo é obtido com a aplicação de $11,8 \mathrm{~kg} \mathrm{~m}^{-2}$ de esterco avícola. Diferenças na composição química do óleo essencial foram observadas para três componentes (mentona, pulegona e acetato de mentila) sem mudança significativa no conteúdo de mentol.
\end{abstract}

Termo para indexação: Mentha piperita, esterco bovino, esterco avícola, análise de crescimento.

(Received in december 20, 2012 and approved in march 3, 2013)

\section{INTRODUCTION}

Mint is a plant that can become cultivated to a variety of climate and common name of approximately 30 perennial species of the genus Mentha (CHAGAS et al., 2011b). Mentha x piperita L. a member of the family Lamiaceae is a rhizomatous aromatic and medicinal plant widely cultivated in many countries. It is popularly known as peppermint, mint or spearmint. Its essential oil is considered industrially important as it is used in pharmaceuticals, confectionery, alcoholic beverages, chewing gum, dental creams and cosmetics (SINGH et al., 2005). For these reasons and others, Mentha piperita oil ranks high in terms of total sales volume (MORAES, 2000). Its leaves are used in numerous therapeutic effects related to its spasmolytic, carminative, stomachic, antiemetic and anthelmintic properties (MCKAV; BLUMBERG, 2006).

Choices for organic foods are increase due to the perception that they are healthier than those grew with synthetic fertilizer (YIRIDOE; BONTI-ANKOMAH; MARTIN, 2007). Some literature supports this belief, showing that organic foods have higher levels of

1Universidade Federal de Goiás/UFG - Departamento de Agronomia - Jataí/Jatobá - Brasil

2Universidade Federal de Lavras/UFLA - Departamento de Agricultura/DAG - Cx. P. 3037- 37200-000 - Lavras - MG - Brasil - suzan@dag.ufla.br. ${ }^{3}$ Empresa Brasileira de Pesquisa Agropecuária/Embrapa Trigo - Rodovia BR 285, Km 294 - Passo Fundo - RS - Brasil

${ }^{4}$ Universidade Federal de Lavras - Departamento de Agricultura/DAG - Lavras - MG - Brasil

Ciênc. agrotec., Lavras, v. 37, n. 3, p. 202-210, maio/jun., 2013 
micronutrients than comparable conventionally grown produce (HUNTER et al., 2011). Thus, nutrition is an important factor that increases both plant productivity and the concentrations of bioactive compounds, thereby improving the quality of medicinal and aromatic plants. During growth and development, medicinal and aromatic plants exhibit phytochemical and physiological changes that can affect the development of the main bioactive compounds, both quantitatively and qualitatively (SHAH; SARAVANAN; GAJBHIYE, 2010). Veronese et al. (2001) stated that mint and mint oil yield are modified by biotic and abiotic factors. This statement is supported by some agronomic studies recorded in the literature, especially those investigating the influence of fertilization on the development of this species. Organic fertilization represents a nutrient source for plants that helps to improve the physical, chemical and biological structure of the soil in addition to providing adequate nourishment.

The ability to reduce both menthofuran and pulegone a level is of commercial significance in improving essential oil quality. Pulegone is a central intermediate in the biosynthesis of menthol, the most significant component of peppermint essential oil. Depending on environmental conditions, this branch point metabolite may be reduced to menthone en route to menthol, by pulegone reductase, or oxidized to menthofuran, by menthofuran synthase (MAHMOUD; CROTEAU, 2003). Scavroni et al (2005) verified that peppermint plant cultivated in presence of biosolid favored menthofuran formation.

Barriers to organic herb greenhouse production are high as a result of lack of available technical information and the low number of producers experienced in this area. It is important to consider the necessity for studies showing the different crops to the presence of organic fertilizer. Thus, the objective of this study was to determine the effects of different sources and doses of organic fertilizer (cattle and poultry manure) on plant growth and the content, yield and chemical composition of peppermint (M. piperita L.) essential oil under conditions of protected cultivation.

\section{MATERIAL AND METHODS}

\section{Preparation of scions and experimental design}

The experiment was conducted in a greenhouse at Lavras ( $21^{\circ} 14^{\prime} \mathrm{S}$ and $45^{\circ} 00^{\prime} \mathrm{W}, 918 \mathrm{~m}$ altitude.) in March to June 2010. The pots were irrigated with water 3 times per week with $700 \mathrm{~mL} /$ pots. Scions were propagated using apical mini-cuttings $(5.0 \mathrm{~cm}$ in length) collected from Mentha x piperita L. plants belonging to UFLA's
Medicinal Plants Garden. The cuttings were grown in polystyrene trays containing the commercial substrate Plantmax Vegetables $\mathrm{HT}^{\circledR}$ in a greenhouse for 35 days. When they had reached $10 \mathrm{~cm}$ in height the scions were transplanted to 10-liter plastic pots containing soil plus the organic fertilizer treatment.

The experimental design was completely randomized using a $2 \times 5$ factorial scheme with four replicates. The treatments consisted of applying two organic fertilizers (cattle and poultry) at one of five doses. The doses used for both the cattle and poultry manure were as follows: 1) soil without manure fertilizer (control); 2) soil + $3.0 \mathrm{~kg} \mathrm{~m}^{-2}$ manure; 3) soil + $6.0 \mathrm{~kg} \mathrm{~m}^{-2}$ manure; 4) soil + $9.0 \mathrm{~kg} \mathrm{~m}^{-2}$ manure; and 5) soil + $12.0 \mathrm{~kg} \mathrm{~m}^{-2}$ manure. Normally the amount of manure was calculated for $\mathrm{m}^{3}$ of soil (hectare has $10000 \mathrm{~m}^{2}$ with a depth of $0.2 \mathrm{~m}$ of soil $=$ $2000 \mathrm{~m}^{3}$ and the pot has $0.01 \mathrm{~m}^{3}$. For instance, $30000 \mathrm{~kg}$ at $2000 \mathrm{~m}^{3}$ in $0.01 \mathrm{~m}^{3}$ will be $0.15 \mathrm{~kg}$ or $150 \mathrm{~g} /$ pot). No chemical fertilizer was applied.

\section{Description of soil and manure}

The soil used as the substrate was collected at a depth of 0-20 cm from a Red-Yellow Latosol. The soil had the following chemical characteristics: $\mathrm{pH}$ in water $=5.6 ; \mathrm{P}$ and $\mathrm{K}\left(\mathrm{mg} \mathrm{dm}{ }^{-3}\right)=0.6$ and 14 , respectively; $\mathrm{Ca}^{+2}, \mathrm{Mg}^{+2}, \mathrm{Al}^{+3}$ and $\mathrm{H}+\mathrm{Al}\left(\mathrm{cmolc} \mathrm{dm}^{-3}\right)=0.5,0.1,0.0$ and 2.1, respectively; and base saturation $\mathrm{V}(\%)=23.4$; organic matter $\left(\mathrm{dag} \mathrm{kg}^{-1}\right)$ $=1.4$. The substrates used as fertilizer had the following values: a) cattle manure: $\mathrm{pH}$ in water $=8.2 ; \mathrm{N}, \mathrm{P}, \mathrm{K}, \mathrm{Na}, \mathrm{Ca}$, $\mathrm{Mg}$ and $\mathrm{S}\left(\mathrm{g} \mathrm{kg}^{-1}\right)=18,5.1,13,1.5,4.1,3.2$ and 2.6, respectively; $\mathrm{B}, \mathrm{Cu}, \mathrm{Fe}, \mathrm{Mn}$ and $\mathrm{Zn}\left(\mathrm{mg} \mathrm{kg}^{-1}\right)=5.6,39$, $12.848,461$ and 150 , respectively; and b) poultry manure: $\mathrm{pH}$ in water $=8.0 ; \mathrm{N}, \mathrm{P}, \mathrm{K}, \mathrm{Na}, \mathrm{Ca}, \mathrm{Mg}$ and $\mathrm{S}\left(\mathrm{g} \mathrm{kg}^{-1}\right)=21,20$, 7.3, 2.2, 4.6, 2.6 and 3.1, respectively; and $\mathrm{B}, \mathrm{Cu}, \mathrm{Fe}, \mathrm{Mn}$ and $\mathrm{Zn}\left(\mathrm{mg} \mathrm{kg}^{-1}\right)=17,74,4.601,315$ and 314, respectively.

\section{Analysis of plant growth}

After 90 days of cultivation the experiments were analyzed by measuring the leaf area $\left(\mathrm{LA} \mathrm{cm}^{2}\right.$ plant $\left.{ }^{-1}\right)$ using an electronic leaf area meter (LI - 3100-LICOR, Lincoln, NE, USA). The physiological parameters of leaf area ratio (LAR, $\mathrm{cm}^{2} \mathrm{~g}^{-1}$ ), specific leaf area (SLA, $\mathrm{cm}^{2} \mathrm{~g}^{-1}$ ) and leaf weight ratio (LWR) (BENINCASA, 2003). The content (\%), yield $\left(\mathrm{g}_{\text {plant }}{ }^{-1}\right)$ and chemical composition of the essential oils were also analyzed.

The plant was separated into roots, stems and leaves and dried in a forced aeration oven, at a temperature of $38 \pm 2^{\circ} \mathrm{C}$ until constant dry matter was achieved. The dried plant material mass was obtained to determine the leaf dry biomass (LDB, g plant ${ }^{-1}$ ), stem dry biomass (SDB, 
g plant ${ }^{-1}$ ), root dry biomass (RDB, g plant ${ }^{-1}$ ) and total plant dry biomass (TDB, g plant $\left.{ }^{-1}\right)$. The root:shoot ratio (R/S) was also determined (BENINCASA, 2003).

\section{Extraction and analysis of essential oil}

The essential oil was extracted from $20 \mathrm{~g}$ of dried leaves by hydrodistillation in a Clevenger-type device for two hours. The oil was separated by decantation for $60 \mathrm{~min}$, and the supernatant was collected. The content (\%), yield ( $\mathrm{ml} \mathrm{g}^{-1}$ dry biomass) and chemical composition of the essential oil were determined. The oil was analyzed quantitatively by a gas chromatograph coupled to a flame ionization detector (GC-FID) on an Agilent ${ }^{\circledR} 7890$ A system fitted with an HP-5MS fused silica capillary column $(30 \mathrm{~m}$ x $25 \mathrm{~mm}$ i.d. x 0.25 ìm film) (Palo Alto, CA, USA). Helium was used as the carrier gas, with a flow of $1.0 \mathrm{ml} / \mathrm{min}$, and the injector and detector temperatures were kept at $220^{\circ}$ $\mathrm{C}$ and $240^{\circ} \mathrm{C}$, respectively. The initial oven temperature was $60^{\circ} \mathrm{C}$, isothermal for $1.5 \mathrm{~min}$, followed by a temperature ramp of $3^{\circ} \mathrm{C} / \mathrm{min}$ to $240^{\circ} \mathrm{C}$ and then a ramp of $10^{\circ} \mathrm{C} / \mathrm{min}$ to $270^{\circ} \mathrm{C}$. The oil was diluted with ethyl acetate $(1 \% \mathrm{v} / \mathrm{v})$ and automatically injected into the chromatograph using an injection volume of $1.0 \mathrm{il} \mathrm{in} \mathrm{split}$ mode at a split ratio of 1:50. The quantitative analysis was performed by integrating the total ion chromatogram (TIC), and the contents of eluted compounds were expressed as the relative percentage of peak areas. The oil was qualitatively analyzed by GC-MS on an Agilent ${ }^{\circledR}$ 5975C system operated by electron impact ionization (70 $\mathrm{eV}$ ) in scanning mode at a speed of $1.0 \mathrm{scan} / \mathrm{s}$, with a mass acquisition interval of $40-400 \mathrm{~m} / \mathrm{z}$. The chromatographic conditions were the same as those used for the quantitative analysis. Compounds were identified by comparing their retention indices relative to the $\mathrm{C}_{8}-\mathrm{C}_{20}$ $n$-alkane series (Sigma Chemical Co., St. Louis, MO, USA) with the values reported in the literature (ADAMS, 2007) and by comparing the mass spectra with the NIST/EPA/ NIH database (NATIONAL INSTITUTE OF STANDARDS AND TECHNOLOGY-NIST, 2008). The retention indices were calculated using the equation of Van Den Dool and Kratz (1963).

\section{Statistical analysis}

The data were analyzed using the software Sisvar $^{\circledR}$ version 5.0 (FERREIRA, 2007). The data were subjected to analyses of variance and polynomial regression at the 5\% level by the F test; the Scott-Knott means comparison test $(\mathrm{p}<0.05)$ was applied when necessary.

\section{RESULTSAND DISCUSSION}

\section{Biomass production}

Treatment with the different doses and sources of organic fertilizers resulted in the growth of a greater biomass of cultivated $M$. piperita. The plants showed wellformed shoots and the dark-green coloration characteristic of this species regardless of the source or dose of organic fertilizer. Plants fertilized with cattle or poultry manure developed more branches compared with the controls.

Both the cattle and poultry manure treatments had significant effects on the biomass production of $M$. piperita. The LDB, SDB and RDB followed a cubic tendency with either cattle or poultry manure fertilization. In contrast, the TDB showed a cubic tendency with the cattle manure and a quadratic tendency with the poultry manure (Figure 1).

The LDB was highest in the $8.3 \mathrm{~kg} \mathrm{~m}^{-2}$ poultry manure treatment, reaching $12.4 \mathrm{~g}$. In plants treated with cattle manure, the maximum yield $(7.6 \mathrm{~g})$ was achieved with the application of $9.0 \mathrm{~kg} \mathrm{~m}^{-2}$ (Figure 1A). This increase in dry biomass may be related to increased nutrient availability and uptake, as observed in $M$. piperita (PEGORARO et al., 2010), and M. arvensis (CHAGAS et al., 2011a). We can justify that peppermint plants did not grow much because mint is a long-day plant and its cultivation was done in pots limiting its growth.

The SDB behaved differently depending on the fertilization system applied. The SDB was reduced in plants treated with the higher doses of poultry manure but higher under increasing doses of cattle manure, peaking at $38.41 \mathrm{~g}$ $\left(4.2 \mathrm{~kg} \mathrm{~m}^{-2}\right)$ and $33.78 \mathrm{~g}\left(9.1 \mathrm{~kg} \mathrm{~m}^{-2}\right)$, respectively (Figure 1B). Some authors have related the increased yield of $M$. piperita (including SDB) to the greater K availability in the nutrient solution (VALMORBIDA et al., 2007). This idea is consistent with the results from the manure analysis, which showed that the $\mathrm{K}$ concentration was twice as high in the cattle manure (13 $\left.\mathrm{g} \mathrm{kg}^{-1}\right)$ as in the poultry manure $\left(7.3 \mathrm{~g} \mathrm{~kg}^{-1}\right)$.

Similar results were obtained for RDB. Greater root biomass accumulation was observed with increasing doses of cattle and poultry manure. The greatest root production $(7.3 \mathrm{~g})$ occurred at a dose of $9.4 \mathrm{~kg} \mathrm{~m}^{-2}$ cattle manure, whereas the highest dose of poultry manure $(9.2$ $\mathrm{kg} \mathrm{m}^{-2}$ ) yielded an RDB of only $5.6 \mathrm{~g}$ (Figure 1C).

The greatest overall TDB (49.05 g) was obtained from plants treated with $5.4 \mathrm{~kg} \mathrm{~m}^{-2}$ poultry manure. Among the cattle manure treatments, the highest TDB (47.14 g) was recorded at a dose of $8.8 \mathrm{~kg} \mathrm{~m}^{-2}$ (Figure 1D). Their results show that a plant's response to fertilization depends on the type of soil, nutrient concentration, organic matter and the source of the fertilizer. 

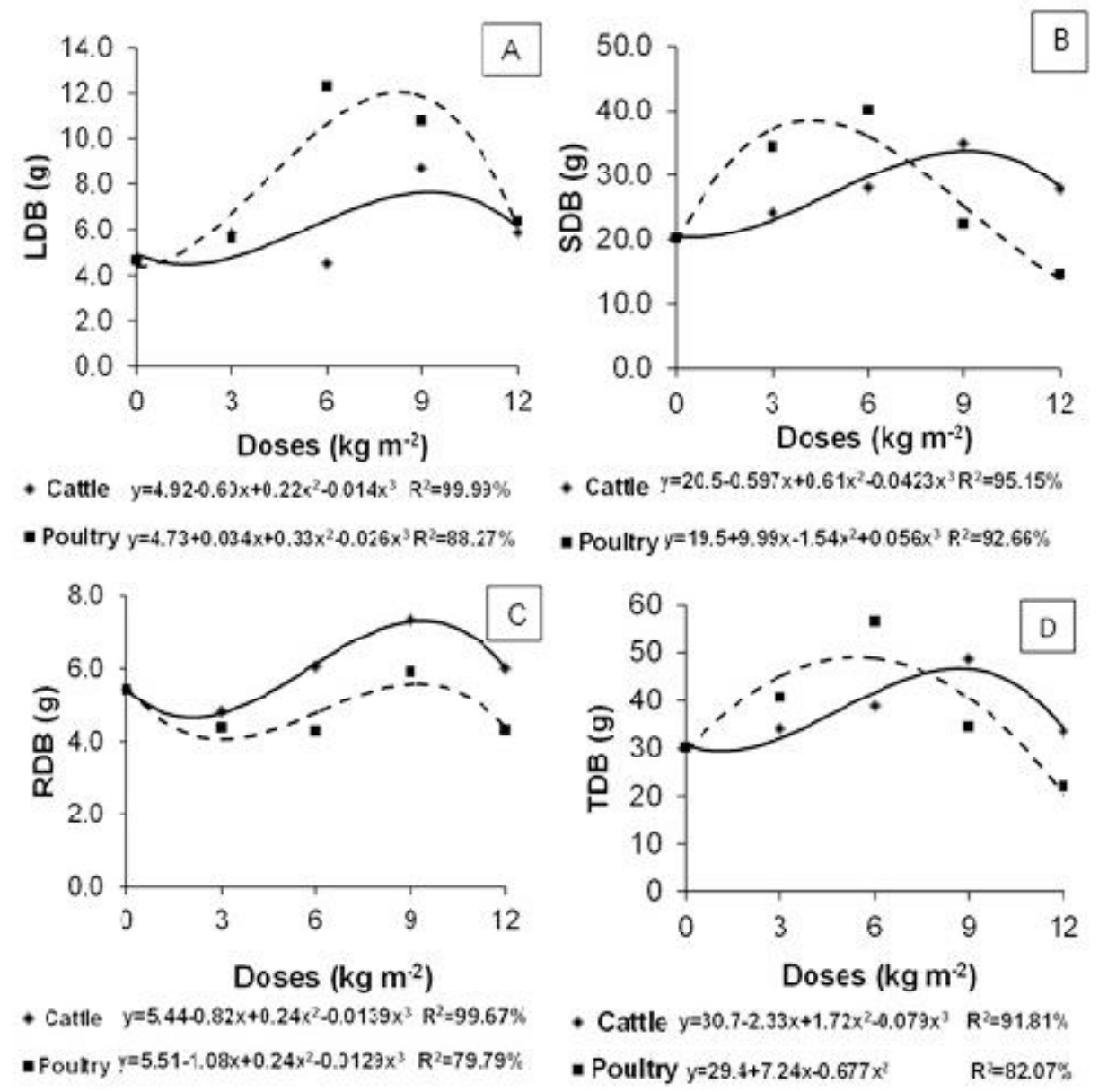

Figure 1 - Dry biomass of the leaves (LDB, A), stems (SDB, B), roots (RDB, C) and total plant (TDB, D) of M. piperita after treatment with different doses of cattle and poultry manure.

Zheljazkov et al. (2010) found that the application of $\mathrm{N}$ and $\mathrm{P}$ improved the productivity of $M$. piperita, increasing both the dry biomass production and essential oil yield. The increase in the biomass of plants fertilized with poultry manure is most likely related to the higher concentrations of $\mathrm{N}$ and $\mathrm{P}$ found in this fertilizer. According to Munsi (1992), elevated dry biomass production at higher $\mathrm{P}$ concentrations may be associated with an increased efficiency of metabolic and physiological processes, which results in greater plant growth, whereas $\mathrm{N}$ may extend the vegetative cycle and thereby increase biomass production. In the present study, the trend toward reduced biomass at higher doses of organic fertilizer can be explained by the excess of nutrients applied to the plants, which may have affected the root system and reduced nutrient absorption. Therefore, knowing the nutritional requirements of different plant species should help to reduce fertilization costs, maximize the harvest and avoid phytotoxic effects. The overabundance of a certain nutrient in the soil reduces the absorption of other nutrients, thereby decreasing plant yield (GUAN et al 2013).

For both types of manure, the highest biomasses were observed in the stems, followed by the leaves and roots. However, the highest LDB was observed in plants treated with poultry manure, highlighting the importance of this fertilizer in the production of the plant part of the greatest economic interest (Table 1).

Physiological growth indexes - there was a significant effect of dose for both types of manure on the LA and LWR. The increase in LA was favored by the use of organic fertilizers, reaching maximum values of 5,296.40 and $3,162.84 \mathrm{~cm}^{2}$ with $8.3 \mathrm{~kg} \mathrm{~m}^{-2}$ poultry manure and $9.6 \mathrm{~kg}$ $\mathrm{m}^{-2}$ cattle manure, respectively (Figure 2). Similar results were reported for M. piperita (PEGORARO et al., 2010). 
Table 1 - Overall averages of dry biomass from leaves (LDB), stems (SDB), roots (RDB) and total plant (TDB) as well as the leaf area (LA), leaf weight ratio (LWR), leaf area ratio (LAR) and specific leaf area (SLA) of M. piperita treated with different doses of cattle and poultry manure.

\begin{tabular}{lrrrr}
\hline \multirow{2}{*}{ Response variable } & \multicolumn{2}{c}{ Fertilizer } & Mean & VC $(\%)$ \\
\cline { 2 - 5 } & \multicolumn{1}{c}{ Cattle } & \multicolumn{1}{c}{ Poultry } & & \\
\hline LDB $\left(\mathrm{g} \mathrm{plant}^{-1}\right)$ & $5.98 \mathrm{~b}$ & $7.93 \mathrm{a}$ & 6.96 & 16.04 \\
SDB $\left(\mathrm{g} \mathrm{plant}^{-1}\right)$ & $27.03 \mathrm{a}$ & $26.03 \mathrm{a}$ & 26.53 & 14.11 \\
RDB $\left(\mathrm{g} \mathrm{plant}^{-1}\right)$ & $5.93 \mathrm{a}$ & $4.86 \mathrm{~b}$ & 5.40 & 11.92 \\
TDB $\left(\mathrm{g} \mathrm{plant}^{-1}\right)$ & $37.08 \mathrm{a}$ & $36.85 \mathrm{a}$ & 36.96 & 16.96 \\
LA $\left(\mathrm{cm}^{2}\right.$ plant $\left.^{-1}\right)$ & $2,534.67 \mathrm{~b}$ & $3,507.05 \mathrm{a}$ & $3,020.86$ & 18.63 \\
LWR $\left(\mathrm{g} \mathrm{g}^{-1}\right)$ & $0.23 \mathrm{a}$ & $0.16 \mathrm{~b}$ & 0.20 & 32.97 \\
LAR $\left(\mathrm{dm}^{2} \mathrm{~g}^{-1}\right)$ & $68.28 \mathrm{~b}$ & $104.08 \mathrm{a}$ & 86.18 & 25.61 \\
SLA $\left(\mathrm{dm}^{2} \mathrm{~g}^{-1}\right)$ & $432.21 \mathrm{a}$ & $449.44 \mathrm{a}$ & 440.83 & 18.11 \\
EO yield $\left(\mathrm{ml} \mathrm{plant}^{-1}\right)$ & $0.0108 \mathrm{a}$ & $0.0110 \mathrm{a}$ & 0.0109 & 14.17 \\
EO Content $(\%)$ & $1.10 \mathrm{a}$ & $1.10 \mathrm{a}$ & 1.10 & 14.98 \\
\hline
\end{tabular}

The highest leaf weight ratio (LWR) values were obtained with $10.8 \mathrm{~kg} \mathrm{~m}^{-2}$ poultry manure $\left(0.33 \mathrm{~g} \mathrm{~g}^{-1}\right)$ and $12.0 \mathrm{~kg} \mathrm{~m}^{-2}$ cattle manure $\left(0.18 \mathrm{~g} \mathrm{~g}^{-1}\right)$. These results suggest that the use of fertilizers allowed a larger fraction of material to be retained in the leaves while decreasing the transport of that material to other parts of the plant (Figure 2B).

There was no significant interaction between the type of manure and the LAR, which increased linearly with higher fertilizer doses (Figure 2C). However, there was an increase in the photosynthetically active leaf area with the application of poultry manure (Table 1). Scavroni et al. (2009) determined that M. piperita plants treated with organic fertilizer showed a higher LWR relative to controls, suggesting that in the presence of biosolids, the plants exhibited a prolonged vegetative phase due to the high concentration of $\mathrm{N}$ present in the substrate. This finding suggests that poultry manure, which contains high $\mathrm{N}$, contributes to the extension of the vegetative phase in plants.

The specific leaf area (SLA) refers to the area of the plant available for photosynthesis. The SLA did not differ significantly among the treatments, suggesting that organic fertilization did not increase leaf thickness (Figure 2D). Scavroni et al. (2009) also found that the SLA remained constant with the use of organic fertilizers.

Regardless of the source of fertilizer, our results showed an average content of essential oil in M. piperita of $1.10 \%$ and a yield of $0.0109 \mathrm{~mL} \mathrm{~g}^{-1}$ (Table 1). This content is within the range of 1.0 to $1.51 \%$ obtained by other authors in studies of this species (VALMORBIDA et al., 2007; SCAVRONI et al., 2009) and above the minimum content required by the Brazilian Pharmacopoeia (BRAZIL, 2010), which is $0.09 \%$ for essential oils extracted from cut leaves.

There is no consensus in the literature regarding the yield of essential oils relative to the use of different types and doses of fertilizers. This lack of consensus may be due to the number and diversity of medicinal plant species and the great variability in the production of secondary metabolites, the biosynthesis of which varies depending on multiple factors that are extrinsic and intrinsic to these species. Similar to the present study with M. piperita, Rosal et al. (2011) found that Plectranthus neochilus responds better to poultry manure among different types of organic fertilizer (cattle, poultry and composite).

Just five major compounds made up 86.0 to $90.9 \%$ of the total chemical composition of the essential oils extracted from plants grown under the different manure treatments. In unfertilized plants, the content of these compounds was $84.8 \%$. In order of elution, the five constituents are menthone (1.9 to $11.7 \%$ ), menthofuran (47.1 to $52.2 \%)$, menthol (14.5 to $18.4 \%)$, pulegone (1.1 and 6.5\%) and menthyl acetate (6.6 to $17.3 \%$ ) (Table 2).

Menthone, pulegone and menthyl acetate showed more pronounced differences in concentration. The lowest menthyl acetate content $(6.6 \%)$ was observed at a dose of $12 \mathrm{~kg} \mathrm{~m}^{-2}$ poultry manure. In contrast, the menthone and pulegone contents were greater in plants treated with poultry manure than in those exposed to cattle manure, independent of dose. The two highest menthone $(8.1 \%$ and $11.7 \%)$ and pulegone $(4.21 \%$ and $6.48 \%)$ contents were obtained at doses of $9 \mathrm{~kg} \mathrm{~m}^{-2}$ and $12 \mathrm{~kg} \mathrm{~m}^{-2}$ poultrymanure, 
respectively (Table 2). Our results show that the increases in the menthone and pulegone contents are most likely associated with the higher concentrations of $\mathrm{N}$ and $\mathrm{P}$ present in these doses of poultry manure (Table 2).

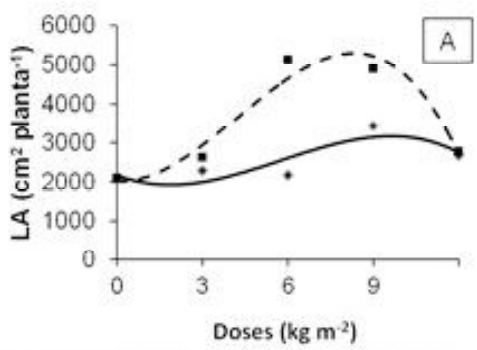

- Cattle $y=2177.2-283.5 x+90.8 x^{2}-5.23 x^{\prime} \quad R^{i}=69.24 \%$

- Poultry $y=2026.3-46.04 x+153.0 x^{3}-12.0 x^{3} R^{2}=95.55 \%$

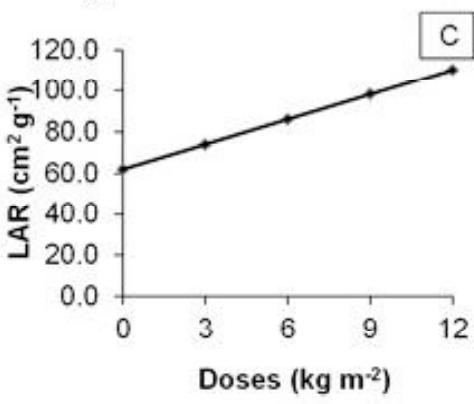

$y=62.009-4.0289 x$

$\mathrm{R}^{2}=82.55 \%$

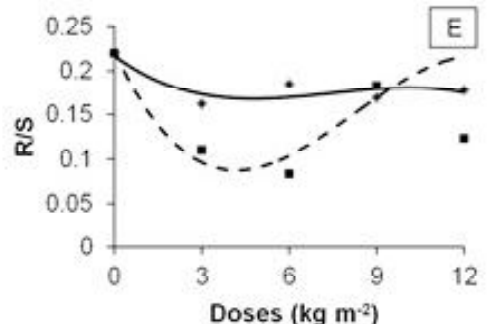

- Cattle y $=0.217-0.024 x+0.004 x^{2}-0.0002 x^{2} R^{2}=75.60 \%$

- Poultry $y=0.223-0.07 x+0.012 x^{2}-0.0005 x^{2} R^{2}=94.41 \%$

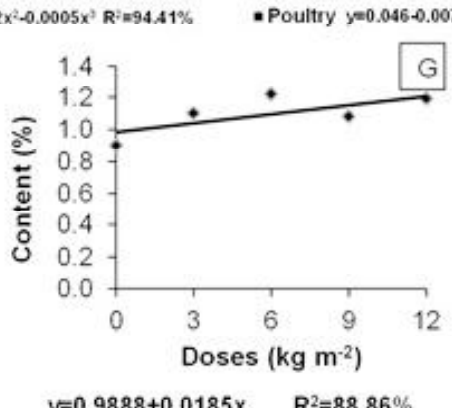

The beneficial effect of the combined application of $\mathrm{N}$ and $\mathrm{P}$ on the production of essential oil in M. piperita and $M$. arvensis was demonstrated by Zheljazkov et al. (2010) and Munsi (1992), respectively.

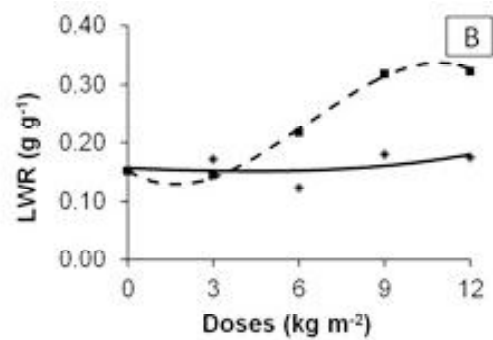

- Cattle $y=0.2-0,0015 x+0.000006 x^{2}-0.00002 x^{3} R^{2}=99 \%$

- Poultry $y=0,1-0,029 x+0.0101 x^{2}-0.00054 x^{2} \quad R^{2}=99.71 \%$

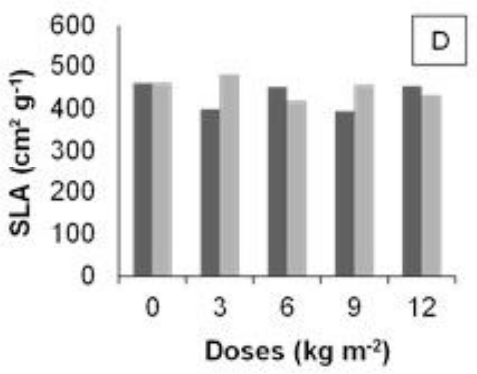

- Cattle in Poultry

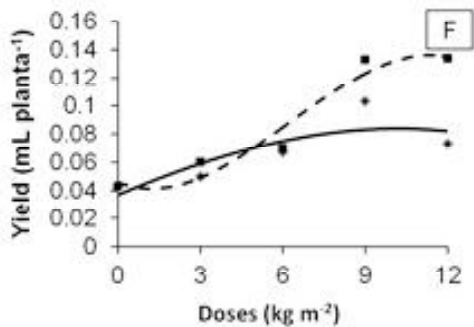

- Cattle $y=0.045-0.009 x+0.004 x^{2}-0.0002 x^{2} \quad R=93,96 \%$

- Poultry $y=0.046-0.007 x+0.003 x^{2}-0.0002 x^{2} R^{2}=93.82 \%$

Figure 2 - Leaf area (LA, A), leaf weight ratio (LWR, B), leaf area ratio (LAR, C), specific leaf area (SLA, D), root:shoot ratio $(\mathrm{R} / \mathrm{S}, \mathrm{E})$, yield $(\mathrm{F})$ and content $(\mathrm{G})$ of essential oil in $M$. piperita after treatment with different doses of cattle and poultry manure.

Ciênc. agrotec., Lavras, v. 37, n. 3, p. 202-210, maio/jun., 2013 
Table 2 - Chemical composition and percentage of peak area of the components of the essential oil from M. piperita leaves exposed to different doses of cattle and poultry manure.

\begin{tabular}{|c|c|c|c|c|c|c|c|c|c|c|}
\hline \multirow{2}{*}{$\begin{array}{l}\text { Treatment } \\
\text { Compound }\end{array}$} & \multirow[b]{2}{*}{$\mathrm{RI}^{*}$} & \multirow{2}{*}{$\begin{array}{c}\begin{array}{c}\text { Without } \\
\text { fertilization }\end{array} \\
0\end{array}$} & \multicolumn{4}{|c|}{ Cattle manure $\left(\mathrm{kg} \mathrm{m}^{-2}\right)$} & \multicolumn{4}{|c|}{ Poultry manure $\left(\mathrm{kg} \mathrm{m}^{-2}\right)$} \\
\hline & & & 3 & 6 & 9 & 12 & 3 & 6 & 9 & 12 \\
\hline$\beta$-Pinene & 966 & 1.1 & 0.8 & 1.0 & 0.8 & 1.0 & 0.9 & 1.0 & 0.9 & 0.9 \\
\hline Limonene & 1012 & 2.7 & 2.5 & 2.8 & 2.2 & 3.0 & 2.5 & 3.0 & 3.1 & 2.7 \\
\hline 1,8-Cineole & 1015 & 2.0 & 1.6 & 1.8 & 1.6 & 1.5 & 1.3 & 1.4 & 1.3 & 1.2 \\
\hline$\gamma$-Terpinene & 1050 & 0.6 & 0.7 & 0.7 & 0.7 & 0.7 & 0.7 & $\mathrm{~T}$ & 0.7 & 0.9 \\
\hline $\begin{array}{l}\text { p-Mentha-2,8- } \\
\text { dienol }\end{array}$ & 1136 & 2.6 & 1.6 & 1.7 & 1.7 & 1.2 & 1.2 & 0.8 & 0.8 & 0.8 \\
\hline Menthone & 1142 & 2.6 & 2.6 & 2.3 & 1.9 & 4.6 & 4.7 & 5.7 & 8.1 & 11.7 \\
\hline Menthofuran & 1153 & 49.5 & 47.1 & 49.7 & 52.2 & 50.8 & 44.1 & 51.2 & 47.9 & 47.9 \\
\hline Menthol & 1163 & 17.2 & 17.6 & 17.5 & 18.4 & 14.5 & 17.9 & 16.0 & 16.3 & 16.9 \\
\hline Pulegone & 1237 & 2.8 & 1.4 & 1.1 & 1.1 & 2.9 & 2.6 & 2.5 & 4.2 & 6.5 \\
\hline $\begin{array}{l}\text { Neomenthyl } \\
\text { Acetate }\end{array}$ & 1278 & 1.0 & 1.4 & 1.3 & 1.0 & 1.3 & 1.5 & 1.0 & 0.9 & 0.5 \\
\hline Menthyl Acetate & 1299 & 12.7 & 17.2 & 16.3 & 14.4 & 14.1 & 17.3 & 13.1 & 14.4 & 6.6 \\
\hline TOTAL & & 94.8 & 94.7 & 96.3 & 96.2 & 95.6 & 94.7 & 92.7 & 98.6 & 96.7 \\
\hline
\end{tabular}

*Retention Index calculated from the n-alkane series on a HP-5MS capillary column in the order of elution.

The European Pharmacopoeia established that $M$. piperita oil should contain between 30-55\% menthol, 14$32 \%$ menthone, $2.8-10 \%$ menthyl acetate and $1-9 \%$ menthofuran (HARRIS, 2006). The M. piperita samples analyzed in the present study also do not meet the requirements of the Brazilian Pharmacopoeia (2010), which establishes a minimum menthol content of $35.0 \%$. The explanation because menthol concentration have been low was due the plants were grown in a greenhouse and the experiment was conducted much South (short-day) than the usual peppermint production areas. We did not have explanation for high amount of menthofuran. Our speculation for high concentration may be due growth conditions inside of greenhouse could enhance the amount of menthofuran. In the present work, M. piperita L. plants did not bloom. This suggests that inadequate photoperiod and temperature conditions occurred inside of greenhouse for this species. This fact may have been responsible for the higher level of menthofuran verified in the plants. It is important to point out that in the present study, harvests to evaluate essential oil began in June; therefore, photoperiod conditions could perhaps justify the menthofuran contents observed. This component showed a tendency to increase as plants progressed in age in this research the plants had 125 days. The best time to harvest mint plants would be at 90 days after planting, since menthol is economically more important than other oil components.

Mahmoud and Croteau, 2003 verified that menthofuran concentration depending on environmental conditions. And, pulegone is a central intermediate in the biosynthesis of menthol, this branch point metabolite may be reduced to menthone en route to menthol, by pulegone reductase, or oxidized to menthofuran, by menthofuran synthase. In the present work this maybe has happened with peppermint cultivated under greenhouse conditions.

\section{CONCLUSIONS}

Different sources and doses organic manure affect plant biomass production and essential oil compounds. Under the conditions of the present work, the metabolic pathway of monoterpenes favored menthofuran synthesis. Menthone, pulegone and menthyl acetate show significant differences in their area percent without changes in the menthol content.

\section{ACKNOWLEDGMENTS}

We thank FAPEMIG, CAPES, CNPq for providing $\mathrm{PhD}$ fellowship, productivity grant, technical support grant and financial support. 


\section{REFERENCES}

ADAMS, R.P. Identification of essential oil components by gas chromatography/mass spectrometry. $4^{\text {th }} \mathrm{ed}$. Illinois: Allured Publishing Corporation, 2007, 804p.

BENINCASA, M. M. P. Plant growth analysis. Jaboticabal: FUNEP, 2003. 41p.

BRAZIL. Brazilian Pharmacopoeia. 5. ed. Brasília: Agência Nacional de Vigilância Sanitária, 2010, v.2, p.1044-1049.

CHAGAS, J.H. et al. Production of Japanese mint in relation to organic fertilization during planting and cover. Horticultura Brasileira, Brasília, v.29, n.3, p.412-417, 2011a.

CHAGAS, J.H. et al. Biomass yield and essential oil content according to age and harvest season in Japanese mint plants. Acta Scientiarum. Agronomy, Maringá, v.33, n.2, p.327-334, 2011b.

FERREIRA,D.F. SISVAR 5.0:statistical analysis system.Lavras:UFLA/DEX,Software.2007.

GUAN, G. Phosphorus fertilization modes affect crop yeld, nutrient uptake, and soil biological properties in the Rice-wheat cropping system. Soil Science Society of America Journal, Madison, v.77, n.1, p. 166-172, 2013.

HARRIS, B. Menthol: a review of its thermoreceptor interactions and their therapeutic applications. The International Journal of Aromatherapy, Amsterdan, v.16, n.3-4, p.117-131, 2006.

HUNTER, D. et al.Evaluation of the micronutrient content of plant foods produced by organic and conventional agricultural methods. Critical Reviews in Food Science and Nutrition, v.51, n.6, p. 571-582, 2011.

MAHMOUD, S. S.; CROTEAU, R. B. Menthofuran regulates essential oil biosynthesis in peppermint_by controlling a downstream monoterpene reductase. Proceedings of the National Academy of Sciences of the United States of America. Washington, v.100, n.24, p.14481-14486, 2003.
McKAV, D.L.; BLUMGERB, J. B. A review of the bioactivity and potential health benefits of peppermint tea (Mentha piperita L.). Phytotherapy Research, v.20, n.8, p.619-633, 2006.

MORAES, J.L.A. Potencial de Mercado para óleos essenciais de oito ervas medicinais, aromáticas e/ou condimentares (MACs). In: Annals of the $1^{\circ}$ Simpósio Latino-Americano de Produção de Plantas Medicinais, Aromáticas e Condimentares. São Pedro, p.923, 2000.

MUNSI, P.S. Nitrogen and phosphorus nutrition response in Japanese mint cultivation. Acta Horticulturae, Leuven, v.306, p.436-442, 1992.

NATIONALINSTITUTE OF STANDARDS AND TECHNOLOGY- NIST. PC version 2.0 of the NIST/ EPA/NIH Mass Spectral Library. Gaithersburg: U.S., Software, 2008.

PEGORARO, R.L. et al. Production of essential oils in plants of Mentha x piperita L. var. piperita

(Lamiaceae) subjected to different light and substrate nutrition levels. Revista Brasileira de Botânica, São Paulo, v.33, n.4, p.631-637, 2010.

ROSAL, L.F. et al. Vegetative and essential oil production of small boldo with respect to organic fertilizers sources. Revista Ceres, Viçosa, v.58, n.5, p.670-678, 2011.

SCAVRONI, J. et al. Development of mint (Mentha piperita L.) grown on biosolids - evaluation of productivity and essential oil content. Brazilian Archives of Biology and Technology, Londrina, v.52, n.2, p.365-377, 2009.

SCAVRONI, J. et al. Yield and composition of the essential oil of Mentha piperita L. (Lamiaceae) grown with biosolid. Brazilian Journal of Plant Physiology, Londrina, v.17, n.4, p.345-352, 2005.

SHAH, S.; SARAVANAN, R.; GAJBHIYE, N. A. Phytochemical and physiological changes in Ashwagandha (Withania somnifera Dunal) under soil moisture stress. Brazilian Journal of Plant Physiology, Londrina, v.22, n.4, p.255-261, 2010. 
SINGH, V.K. et al. Essential oil composition and chemoarrays of menthol mint (Mentha arvensis L. f. piperascens Malinvaud ex. Holmes) cultivars. Flavour and Fragrance Journal, Malden, v.20, n.3, p.302-305, 2005.

SRIVASTAVA, R.K. et al. Characteristics of menthol mint Mentha arvensis cultivated on industrial scale in the Indo-Gangetic plains. Industrial Crops and

Products, Amsterdan, v.15, n.3, p.189-198, 2002.

VALMORBIDA, J. et al. Growth of Mentha piperita L. grown in nutrient solution with different doses of potassium. Brazilian Journal of Medicinal Plants, Campinas, v.9, n.4, p.27-31, 2007.

VAN DEN DOOL, H.; KRATZ, P.D.J.A. Generalization of the retention index system including linear temperature programmed gas-liquid partition chromatography. Journal of Chromatography, Amsterdan, v.11, p.463-471, 1963.

VERONESE, P. et al. Bioengineering mint crop improvement. Plant Cell Tissue Organ Culture, New York, v.64, n.2-3, p.133-144, 2001.

YIRIDOE, E.K.; BONTI-ANKOMAH, S.; MARTIN, R.C. Comparison of consumer perceptions and preference toward organic versus conventionally produced foods: A review and update of the literature. Renewable Agriculture and Food Systems,

Cambridge, v.20, n.4, p.193-205, 2007.

ZHELJAZKOV, V.D. et al. Peppermint productivity and oil composition as a function of nitrogen, growth stage, and harvest time. Agronomy Journal, Madison, v.102, n.1, p.124-128, 2010.

Ciênc. agrotec., Lavras, v. 37, n. 3, p. 202-210, maio/jun., 2013 